\title{
Study on the biodegradation of perfluorooctanesulfonate (PFOS) and PFOS alternatives
}

\author{
Bongin Choi ${ }^{1}$, Suk-Hyun $\mathrm{Na}^{1}$, Jun-Hyo Son ${ }^{1}$, Dong-Soo Shin ${ }^{2}$, Byung-Taek Ryu ${ }^{3}$, \\ Kyun-Suk Byeon ${ }^{2}$, Seon-Yong Chung ${ }^{1}$ \\ ${ }^{1}$ Department of Environment and Energy Engineering, Chonnam National University College of Engineering, Gwangju; \\ ${ }^{2}$ Department of Chemistry, Changwon National University, Changwon; ${ }^{3}$ Environmental Safety Center, Korea Environmental \\ Corporation, Incheon, Korea
}

\begin{abstract}
Objectives In this study, we investigated the biodegradation features of 4 perfluorooctanesulfonate (PFOS) alternatives developed at Changwon National University compared to those of PFOS.

Methods Biodegradation testing was performed with microorganisms cultured in the good laboratory practice laboratory of the Korea Environment Corporation for 28 days following the Organization for Economic Cooperation and Development guidelines for the testing of chemicals (Test No. $301 \mathrm{C}$ ).

Results While $\mathrm{C}_{8} \mathrm{~F}_{17} \mathrm{SO}_{3} \mathrm{Na}$, PFOS sodium salt was not degraded after 28 days, the 4 alternatives were biodegraded at the rates of $20.9 \%$ for $\mathrm{C}_{15} \mathrm{~F}_{9} \mathrm{H}_{21} \mathrm{~S}_{2} \mathrm{O}_{8} \mathrm{Na}_{2}$, 8.4\% for $\mathrm{C}_{17} \mathrm{~F}_{9} \mathrm{H}$ ${ }_{25} \mathrm{~S}_{2} \mathrm{O}_{8} \mathrm{Na}_{2}$, 22.6\% for $\mathrm{C}_{23} \mathrm{~F}_{18} \mathrm{H}_{28} \mathrm{~S}_{2} \mathrm{O}_{8} \mathrm{Na}_{2}$, and $23.6 \%$ for $\mathrm{C}_{25} \mathrm{~F}_{17} \mathrm{H}_{32} \mathrm{O}_{13} \mathrm{~S}_{3} \mathrm{Na}_{3}$.

Conclusions $\mathrm{C}_{25} \mathrm{~F}_{17} \mathrm{H}_{32} \mathrm{~S}_{3} \mathrm{O}_{13} \mathrm{Na}_{3}, \mathrm{C}_{23} \mathrm{~F}_{18} \mathrm{H}_{28} \mathrm{~S}_{2} \mathrm{O}_{8} \mathrm{Na}_{2}$, and $\mathrm{C}_{15} \mathrm{~F}_{9} \mathrm{H}_{21} \mathrm{~S}_{2} \mathrm{O}_{8} \mathrm{Na}_{2}$ were superior to PFOS in terms of biodegradation rates and surface tension, and thus they were considered highly applicable as PFOS alternatives. Environmental toxicity, human toxicity, and economic feasibility of these compounds should be investigated prior to their commercialization.
\end{abstract}

Keywords Perfluorooctanesulfonate, Alternatives, Persistent organic pollutants
Correspondence: Seon-Yong Chung 77 Yongbong-ro, Buk-gu, Gwangju 61186, Korea

Tel: $+82-62-530-1858$

Fax: +82-62-530-0742

E-mail: sychung@jnu.ac.kr

Received: October 16, 2015 Accepted: January 29, 2016

Published: January 29, 2016

This article is available from: http://e-eht.org/

\section{Introduction}

Perfluorooctanesulfonic acid (PFOS), a perfluorinated compound, is a synthetic compound. Since PFOS has excellent qualities in terms of surface activity, water repellency, oil repellency, thermal resistance, chemical resistance, and rub resistance, it has been broadly applied broadly as a fire fighting foam, coating agent for items such as carpet,clothing, paper, and leather, commercial stain-preventing agent, metal cleaner, and aviation hydraulic fluids. As such, PFOS is of high value for both industrial and consumer uses; however, PFOS is not easily degraded and remains in the environment or the human body for a long period of time $[1,2]$.
A cerebellar test in rats showed that PFOS caused neurotoxicity and decreased the survival rate of infant rats in pregnant rats, causing reproductive toxicity. A recent study reported $6.06 \mathrm{ng} /$ $\mathrm{mL}$ as the mean blood concentration of PFOS in Koreans [3].

Thus, PFOS was listed as a persistent organic pollutant during the 4th Conference of the Parties in the Stockholm Convention held in Geneva, Switzerland, May 2009, and was officially announced on August 26, 2010 after public comment periods of the countries directly involved. In South Korea (hereafter Korea), the enforcement ordinance for the Persistent Organic Pollutants Control Act was revised on April 11, 2011, listing PFOS and PFOS salts as persistent organic pollutants and strictly limiting their production, export, and use. 
Although $3 \mathrm{M}$ volutariliy suspended its PFOS production in 2002 and developed alternatives including perfluorobutanesulfonate with a reduced number of carbon chains, a fully replacable material for PFOS has not been developed. The present study investigated the biodegradation features of 4 types of PFOS alternatives developed by Vijaykumar et al. [4] and compared these molceules to PFOS.

\section{Materials and Methods}

\section{Test Substances}

Test substances for biodegradation testing included 4 types of PFOS alternatives synthesized in the laboratory of professor Dong Soo Shin at Changwon National University and included $\mathrm{C}_{15} \mathrm{~F}_{9} \mathrm{H}_{21} \mathrm{~S}_{2} \mathrm{O}_{8} \mathrm{Na}_{2}$ (molecular weight [MW], 610.42), $\mathrm{C}_{17} \mathrm{~F}_{9} \mathrm{H}$ ${ }_{25} \mathrm{~S}_{2} \mathrm{O}_{8} \mathrm{Na}_{2}$ (MW, 638.47), $\mathrm{C}_{23} \mathrm{~F}_{18} \mathrm{H}_{28} \mathrm{~S}_{2} \mathrm{O}_{8} \mathrm{Na}_{2}$ (MW, 884.54), and $\mathrm{C}_{25} \mathrm{~F}_{17} \mathrm{H}_{32} \mathrm{~S}_{3} \mathrm{O}_{13} \mathrm{Na}_{3}(\mathrm{MW}, 1028.65)$ as well as $\mathrm{C}_{8} \mathrm{~F}_{17} \mathrm{SO}_{3} \mathrm{Na}$ (MW, 522.11), a PFOS in sodium salt.

\section{Test Methods and Microorganisms}

Biodegradation testing was performed following the Organization for Economic Cooperation and Development (OECD) guidelines for the testing of chemicals (Test No. 301C).

Microorganisms used for the test were collected from 10 sites in Korea such as municipal sewage treatment plants, industry waste water treatment plants, rivers, lakes, and the sea, and cultured in the good laboratory practice laboratory of the Korea Environment Corporation for at least 1 month.

\section{Test Equipment}

An OxiTop Control (OxiTop Control 100, WTW, Weilheim, Germany) was used to measure the biodegradation rate according to the test method in the OECD guidelines for the testing of chemicals (Test No. 301 C). The OxiTop Control measures biochemical oxygen demand (BOD) in real-time based on pressure changes within a tightly closed test bottle. The machine is composed of test bottles, measurement heads, a remote controller, and an agitation system.

\section{Biodegradation Test}

One type of PFOS sodium salt $\left(\mathrm{C}_{8} \mathrm{~F}_{17} \mathrm{SO}_{3} \mathrm{Na}\right)$ and 4 alternatives $\left(\mathrm{C}_{15} \mathrm{~F}_{9} \mathrm{H}_{21} \mathrm{~S}_{2} \mathrm{O}_{8} \mathrm{Na}_{2}, \mathrm{C}_{17} \mathrm{~F}_{9} \mathrm{H}_{25} \mathrm{~S}_{2} \mathrm{O}_{8} \mathrm{Na}_{2}, \mathrm{C}_{23} \mathrm{~F}_{18} \mathrm{H}_{28} \mathrm{~S}_{2} \mathrm{O}_{8} \mathrm{Na}_{2}\right.$, $\mathrm{C}_{25} \mathrm{~F}_{17} \mathrm{H}_{32} \mathrm{~S}_{3} \mathrm{O}_{13} \mathrm{Na}_{3}$ ) were subjected to biodegradation testing.

A total of $0.015 \mathrm{~g}$ each of the 5 test substances $\left(\mathrm{C}_{8} \mathrm{~F}_{17} \mathrm{SO}_{3} \mathrm{Na}\right.$, $\mathrm{C}_{15} \mathrm{~F}_{9} \mathrm{H}_{21} \mathrm{~S}_{2} \mathrm{O}_{8} \mathrm{Na}_{2}, \mathrm{C}_{17} \mathrm{~F}_{9} \mathrm{H}_{25} \mathrm{~S}_{2} \mathrm{O}_{8} \mathrm{Na}_{2}, \mathrm{C}_{23} \mathrm{~F}_{18} \mathrm{H}_{28} \mathrm{~S}_{2} \mathrm{O}_{8} \mathrm{Na}_{2}, \mathrm{C}_{25} \mathrm{~F}-$ ${ }_{17} \mathrm{H}_{32} \mathrm{~S}_{3} \mathrm{O}_{13} \mathrm{Na}_{3}$ ) was transferred into bottles \#1 to \#5, and then $150 \mathrm{~mL}$ of deionized water (DW) was added to each bottle.

For bottles \#6 to \#20, each of the 5 test substances $\left(\mathrm{C}_{15} \mathrm{~F}_{9} \mathrm{H}\right.$ -
${ }_{21} \mathrm{~S}_{2} \mathrm{O}_{8} \mathrm{Na}_{2}, \mathrm{C}_{17} \mathrm{~F}_{9} \mathrm{H}_{25} \mathrm{~S}_{2} \mathrm{O}_{8} \mathrm{Na}_{2}, \mathrm{C}_{23} \mathrm{~F}_{18} \mathrm{H}_{28} \mathrm{~S}_{2} \mathrm{O}_{8} \mathrm{Na}_{2}, \mathrm{C}_{25} \mathrm{~F}_{17} \mathrm{H}-$ ${ }_{32} \mathrm{~S}_{3} \mathrm{O}_{13} \mathrm{Na}_{3}$ ) was added to make 3 replicates. To each test bottle, we added $0.015 \mathrm{~g}$ of each test substance (final concentration of test substance, $100 \mathrm{mg} / \mathrm{L}$ ), $1.8 \mathrm{~mL}$ basic medium, $143.64 \mathrm{~mL}$ DW, and $4.56 \mathrm{~mL}$ microorganisms (concentration, $30 \mathrm{ppm}$; dry weight, $9.9 \mathrm{mg}$ ). To evaluate the conditions of the microorganisms, bottle \#21 contained $0.015 \mathrm{~g}$ aniline $\left(\mathrm{C}_{6} \mathrm{H}_{7} \mathrm{~N}, 99.6 \%\right.$; Sigma-Aldrich, St. Louis, MO, USA) (100 mg/L) as a control substance, $1.8 \mathrm{~mL}$ basic medium, $143.64 \mathrm{~mL} \mathrm{DW}$, and $4.6 \mathrm{~mL}$ microorganisms. In order to compare the biodegradation rates of the 5 test substances, bottle \#22 contained $1.8 \mathrm{~mL}$ basic medium, $143.64 \mathrm{~mL}$ DW, and $4.56 \mathrm{~mL}$ microorganisms. These 22 prepared test bottles were placed on the agitation system after setting the remote controller and then incubated for 28 days. The internal temperature of the incubator was $24.9^{\circ} \mathrm{C}$ to $25.1^{\circ} \mathrm{C}$ and the $\mathrm{pH}$ was 6.70 to 7.92 .

The biodegradation rate (\%) of test substances was calculated as follows:

$$
\text { Biodegradation rate }(\%)=\frac{\text { Biochemical oxygen demand of test substance }}{\text { Theoretical oxygen demand of test substance }} \times 100
$$

The BOD of the Test Substances was Calculated as Follows: BOD $(\mathrm{mg} / \mathrm{L})$ of test substances $=($ mean BOD of 3 replicates of each test substance [e.g., BOD of bottle \#6+ BOD of bottle $\# 7+$ BOD of bottle \#8/3])-(each BOD of bottle \#1, BOD of bottle \#2, BOD of bottle \#3, BOD of bottle \#4, or BOD of bottle $\# 5+(\mathrm{BOD}$ of bottle $\# 5+\mathrm{BOD}$ of bottle \#22))/concentration of each test substance

The BOD of the control substance was calculated as follows: $\mathrm{BOD}(\mathrm{mg} / \mathrm{L})$ of control substance $=(\mathrm{BOD}$ of bottle $\# 21-\mathrm{BOD}$ of bottle \#22)/concentration of control substance

The theoretical oxygen demand (ThOD) ThOD of the test substances or control substance was calculated as follows:

$$
\begin{aligned}
& \mathrm{C}_{\mathrm{c}} \mathrm{H}_{\mathrm{h}} \mathrm{F}_{\mathrm{f}} \mathrm{N}_{\mathrm{n}} \mathrm{Na}_{\mathrm{na}} \mathrm{O}_{\mathrm{o}} \mathrm{P}_{\mathrm{p}} \mathrm{S}_{\mathrm{s}} \\
& \operatorname{ThOD}(\mathrm{mg} / \mathrm{L})=16(2 \mathrm{c}+1 / 2[\mathrm{~h}-\mathrm{f}-3 \mathrm{n}]+3 \mathrm{~s}+5 / 2 \mathrm{p}+1 / 2 \mathrm{na}-\mathrm{o}) / \mathrm{MW}
\end{aligned}
$$

\section{Isolation and Identification of Degrading Microorganisms}

A mineral medium produced in the biodegradation laboratory of Chonnam National University was used as a medium for the isolation of microorganisms. The only carbon source in the medium was the PFOS alternatives used in the test. Microorganisms were cultured in a $35^{\circ} \mathrm{C}$ incubator under aerobic conditions for 24 hours and visually inspected for proliferation, followed by sub-culture on solid media at least 5 times. The isolated microorganisms were subjected to DNA sequencing of the $16 \mathrm{~S}$ rRNA genes for identification. 


\section{Results}

The degradation rate of aniline, the control substance, was $73.7 \%$ on the 7 th day and $83.6 \%$ on the 14 th day, confirming the normal states of the microorganisms used in the study (if the degradation rate is $40 \%$ or more on the 7 th day and $65 \%$ or more on the 14th day, the microorganisms were considered to be normal based on the criteria of the OECD guidelines for the testing of chemicals, Test No. $301 \mathrm{C}$ ). For $\mathrm{C}_{8} \mathrm{~F}_{17} \mathrm{SO}_{3} \mathrm{Na}$, the sodium salt PFOS, the mean BODs were 6.53, 17.60, and 30.57 $\mathrm{mg} / \mathrm{L}$ on the $7 \mathrm{th}, 14 \mathrm{th}$, and 28 th days, respectively. The BODs of the group without test substance (blank) were 13.20, 24.10, and $35.80 \mathrm{mg} / \mathrm{L}$ on the 7 th, 14 th, and 28th days, respectively. When $\mathrm{C}_{15} \mathrm{~F}_{9} \mathrm{H}_{21} \mathrm{~S}_{2} \mathrm{O}_{8} \mathrm{Na}_{2}$ was tested, the BODs were 20.60, 42.70 , and $54.97 \mathrm{mg} / \mathrm{L}$ on the 7th, 14th, and 28th days, respectively. The mean BODs of $\mathrm{C}_{17} \mathrm{~F}_{9} \mathrm{H}_{25} \mathrm{~S}_{2} \mathrm{O}_{8} \mathrm{Na}_{2}$ were 19.90, 31.10, and $44.53 \mathrm{mg} / \mathrm{L}$ on the $7 \mathrm{th}, 14 \mathrm{th}$, and 28th days, respectively. When $\mathrm{C}_{23} \mathrm{~F}_{18} \mathrm{H}_{28} \mathrm{~S}_{2} \mathrm{O}_{8} \mathrm{Na}_{2}$ was added, the mean BODs were $18.83,35.20$, and $49.80 \mathrm{mg} / \mathrm{L}$ on the 7th, 14th, and 28th days, respectively. $\mathrm{C}_{25} \mathrm{~F}_{17} \mathrm{H}_{32} \mathrm{~S}_{3} \mathrm{O}_{13} \mathrm{Na}_{3}$ addition resulted in mean BOD values of $26.53,43.10$, and $56.30 \mathrm{mg} / \mathrm{L}$ on the $7 \mathrm{th}, 14 \mathrm{th}$, and 28th days, respectively (Table 1).

When the degradation rates were calculated using the biodegradation calculating formula, $\mathrm{C}_{8} \mathrm{~F}_{17} \mathrm{SO}_{3} \mathrm{Na}$, $\mathrm{PFOS}$ sodium salt showed a negative value, indicating that no degradation occurred over the 28 days. The biodegradation rate of $\mathrm{C}_{15} \mathrm{~F}_{9} \mathrm{H}$ ${ }_{21} \mathrm{~S}_{2} \mathrm{O}_{8} \mathrm{Na}_{2}$ was $8.1 \%, 20.2 \%$, and $20.9 \%$ on the 7 th, 14 th, and 28th days, respectively. The biodegradation rate of $\mathrm{C}_{17} \mathrm{~F}_{9} \mathrm{H}-$ ${ }_{25} \mathrm{~S}_{2} \mathrm{O}_{8} \mathrm{Na}_{2}$ was $6.6 \%, 6.8 \%$, and $8.4 \%$ on the 7 th, 14 th, and 28 th days, respectively. In addition, the biodegradation rate of $\mathrm{C}_{23} \mathrm{~F}-$ ${ }_{18} \mathrm{H}_{28} \mathrm{~S}_{2} \mathrm{O}_{8} \mathrm{Na}_{2}$ was $14.7 \%, 21.0 \%$, and $22.6 \%$ on the 7 th, 14 th, and 28th days, respectively. Finally, the biodegradation rate of $\mathrm{C}_{25} \mathrm{~F}_{17} \mathrm{H}_{32} \mathrm{~S}_{3} \mathrm{O}_{13} \mathrm{Na}_{3}$ was $15.5 \%, 22.2 \%$, and $23.6 \%$ on the 7 th, 14th, and 28th days, respectively (Table 2).

Microorganisms capable of degrading the 4 PFOS alternatives were isolated and identified based on their DNA sequences.
The DNA sequences of $\mathrm{C}_{15} \mathrm{~F}_{9} \mathrm{H}_{21} \mathrm{~S}_{2} \mathrm{O}_{8} \mathrm{Na}_{2}$-degrading microorganisms showed $99 \%$ and 96\% homology with those of Pandoraea oxalativorans and Ralstonia solanacearum, respectively. For $\mathrm{C}_{17} \mathrm{~F}_{9} \mathrm{H}_{25} \mathrm{~S}_{2} \mathrm{O}_{8} \mathrm{Na}_{2}$, the DNA sequences showed $99 \%$ homology with of the sequences of Flectobacillus roseus and Sphingomonas echinoides. Microorganisms degrading $\mathrm{C}_{23} \mathrm{~F}_{18} \mathrm{H}_{28} \mathrm{~S}_{2} \mathrm{O}$ ${ }_{8} \mathrm{Na}_{2}$ showed $100 \%$ of homology with both Dyadobacter fermentans and Pseudomonas umsongensis. Those of $\mathrm{C}_{25} \mathrm{~F}_{17} \mathrm{H}_{32} \mathrm{~S}_{3} \mathrm{O}_{13} \mathrm{Na}_{3}$ showed 99\% homology with Bacillus cereus and Achromobacter denitrificans (Figure 1).

Table 2. Biodegradation of perfluorooctanesulfonate (PFOS) alternatives and PFOS sodium salt

\begin{tabular}{lrcr}
\hline \multirow{2}{*}{ Chemicals } & \multicolumn{3}{c}{ Biodegradation (\%) } \\
\cline { 2 - 4 } & $7 \mathrm{~d}$ & $14 \mathrm{~d}$ & $28 \mathrm{~d}$ \\
\hline $\mathrm{C}_{8} \mathrm{~F}_{17} \mathrm{SO}_{3} \mathrm{Na}$, PFOS & 0.0 & 0.0 & 0.0 \\
$\mathrm{C}_{15} \mathrm{~F}_{9} \mathrm{H}_{21} \mathrm{~S}_{2} \mathrm{O}_{8} \mathrm{Na}_{2}$ & 8.1 & 20.2 & 20.9 \\
$\mathrm{C}_{17} \mathrm{~F}_{9} \mathrm{H}_{25} \mathrm{~S}_{2} \mathrm{O}_{8} \mathrm{Na}_{2}$ & 6.6 & 6.8 & 8.4 \\
$\mathrm{C}_{23} \mathrm{~F}_{18} \mathrm{H}_{28} \mathrm{~S}_{2} \mathrm{O}_{8} \mathrm{Na}_{2}$ & 14.7 & 21.0 & 22.6 \\
$\mathrm{C}_{25} \mathrm{~F}_{17} \mathrm{H}_{32} \mathrm{~S}_{3} \mathrm{O}_{13} \mathrm{Na}_{3}$ & 15.5 & 22.2 & 23.6 \\
\hline
\end{tabular}

\begin{tabular}{ll}
\hline Chemicals & \multicolumn{1}{c}{ Strains } \\
\hline $\mathrm{C}_{15} \mathrm{~F}_{9} \mathrm{H}_{21} \mathrm{~S}_{2} \mathrm{O}_{8} \mathrm{Na}_{2}$ & (1) Pandoraea oxalativorans \\
& (2) Ralstonia solanacearum \\
& \\
$\mathrm{C}_{17} \mathrm{~F}_{9} \mathrm{H}_{25} \mathrm{~S}_{2} \mathrm{O}_{8} \mathrm{Na}_{2}$ & (3) Flectobacillus roseus \\
& (4) Sphingomonas echinoides \\
$\mathrm{C}_{23} \mathrm{~F}_{18} \mathrm{H}_{28} \mathrm{~S}_{2} \mathrm{O}_{8} \mathrm{Na}_{2}$ & (5) Dyadobacter fermentans \\
& (6) Pseudomonas umsongensis \\
$\mathrm{C}_{25} \mathrm{~F}_{17} \mathrm{H}_{32} \mathrm{~S}_{3} \mathrm{O}_{13} \mathrm{Na}_{3}$ & (7) Bacillus cereus \\
& (8) Achromobacter denitrificans
\end{tabular}

Figure 1. Separated bacteria strains from perfluorooctanesulfonic acid (PFOS) alternatives.

Table 1. BOD and ThOD of PFOS alternatives and PFOS sodium salt

\begin{tabular}{lcccc}
\hline Chemicals & & BOD (mg/L) & ThOD (mg/L) \\
\cline { 2 - 4 } & $7 \mathrm{~d}$ & $14 \mathrm{~d}$ & 0.0 & $0.28 \mathrm{~d}$ \\
\hline Test substances+DW & 0.0 & 0.0 & $30.57 \pm 0.25$ & 0.24 \\
$\mathrm{C}_{8} \mathrm{~F}_{17} \mathrm{SO}_{3} \mathrm{Na}$, PFOS & $6.53 \pm 0.06$ & $47.60 \pm 0.10$ & $54.97 \pm 0.35$ & 0.92 \\
$\mathrm{C}_{15} \mathrm{~F}_{9} \mathrm{H}_{21} \mathrm{~S}_{2} \mathrm{O}_{8} \mathrm{Na}_{2}$ & $20.60 \pm 0.30$ & $31.10 \pm 1.10$ & $44.53 \pm 0.15$ & 1.03 \\
$\mathrm{C}_{17} \mathrm{~F}_{9} \mathrm{H}_{25} \mathrm{~S}_{2} \mathrm{O}_{8} \mathrm{Na}_{2}$ & $19.90 \pm 0.90$ & $35.20 \pm 0.30$ & $49.80 \pm 0.20$ & 0.90 \\
$\mathrm{C}_{23} \mathrm{~F}_{18} \mathrm{H}_{28} \mathrm{~S}_{2} \mathrm{O}_{8} \mathrm{Na}_{2}$ & $18.83 \pm 0.35$ & $43.10 \pm 0.40$ & $56.30 \pm 1.00$ & 0.85 \\
$\mathrm{C}_{25} \mathrm{~F}_{17} \mathrm{H}_{32} \mathrm{~S}_{3} \mathrm{O}_{13} \mathrm{Na}_{3}$ & $26.53 \pm 0.55$ & 24.1 & 35.8 & \\
Blank & 13.2 & &
\end{tabular}

Values are presented as mean \pm standard deviation.

BOD, biochemical oxygen demand; ThoD, theoretical oxygen demand; PFOS, perfluorooctanesulfonate; DW, deionized water. 


\section{Discussion}

$\mathrm{C}_{8} \mathrm{~F}_{17} \mathrm{SO}_{3} \mathrm{Na}$, the PFOS sodium salt, was not degraded by microorganisms over the 28-day experimental period. The biodegradation rates of $\mathrm{C}_{25} \mathrm{~F}_{17} \mathrm{H}_{32} \mathrm{~S}_{3} \mathrm{O}_{13} \mathrm{Na}_{3}$ and $\mathrm{C}_{23} \mathrm{~F}_{18} \mathrm{H}_{28} \mathrm{~S}_{2} \mathrm{O}_{8} \mathrm{Na}_{2}$, which have 3 times as many carbons but similar numbers of fluorines (17 and 18 ), were $22.6 \%$ and $23.6 \%$, respectively, showing the highest degradation rates. The next highest biodegradation rate was $20.9 \%$ of $\mathrm{C}_{15} \mathrm{~F}_{9} \mathrm{H}_{21} \mathrm{~S}_{2} \mathrm{O}_{8} \mathrm{Na}_{2}$, which contained 15 carbon atoms and only 9 fluorine atoms. PFOS has superior features in surface activity, water repellency, and oil repellency because of its low surface tension. When surface tension was measured at the same concentration $(500 \mathrm{mg} / \mathrm{L})$ using a tensiometer (KSV Sigma 702, Biolin Scientific, Stockholm, Sweden), the surface tension of the 4 PFOS alternatives was 20.94 to 28.17 $\mathrm{mN} / \mathrm{m}$, whereas that of the PFOS sodium salt $\mathrm{C}_{8} \mathrm{~F}_{17} \mathrm{SO}_{3} \mathrm{Na}$ was $46.18 \mathrm{mN} / \mathrm{m}$. Taken together, the 3 substances $\left(\mathrm{C}_{23} \mathrm{~F}_{18} \mathrm{H}_{28} \mathrm{O}_{8} \mathrm{~S}\right.$ ${ }_{2} \mathrm{Na}_{2}, \mathrm{C}_{25} \mathrm{~F}_{17} \mathrm{H}_{32} \mathrm{O}_{13} \mathrm{~S}_{3} \mathrm{Na}_{3}, \mathrm{C}_{15} \mathrm{~F}_{9} \mathrm{H}_{21} \mathrm{O}_{8} \mathrm{~S}_{2} \mathrm{Na}_{2}$ ), which showed biodegradation rates of higher than $20 \%$, were determined to be highly applicable as PFOS alternatives. However, they should be investigated further to determine their environmental toxicity, human toxicity, and economic feasibility before commercialization as PFOS alternatives.

\section{Acknowledgements}

This study was funded by the Korea Environmental Industry and Technology Institute, the Ministry of Environment (KME, 412-111-008).

\section{Conflict of Interest}

The authors have no conflicts of interest associated with material presented in this paper.

\section{ORCID}

Bongin Choi http://orcid.org/0000-0002-4563-8337

Suk-Hyun Na http://orcid.org/0000-0001-6148-7308

Jun-Hyo Son http://orcid.org/0000-0002-3611-7193

Dong-Soo Shin http://orcid.org/0000-0002-7948-0419

Byung-Taek Ryu http://orcid.org/0000-0003-2931-6060

Kyun-Suk Byeon http://orcid.org/0000-0002-2097-3825

Seon-Yong Chung http://orcid.org/0000-0001-8664-9625

\section{References}

1. Martin JW, Muir DC, Moody CA, Ellis DA, Kwan WC, Solomon $\mathrm{KR}$, et al. Collection of airborne fluorinated organics and analysis by gas chromatography/chemical ionization mass spectrometry. Anal Chem 2002;74(3):584-590.

2. Higgins CP, Field JA, Criddle CS, Luthy RG. Quantitative determination of perfluorochemicals in sediments and domestic sludge. Environ Sci Technol 2005;39(11):3946-3956.

3. Suh C, Lee CK, Lee SR, Park MH, Lee JT, Son BC, et al. Concentration of PFOA and PFOS in whole blood and factors controlling their exposure among Koreans. J Environ Health Sci 2012:38(2):105-117 (Korean).

4. Vijaykumar BV, Premkumar B, Jang K, Choi BI, Falck JR, Sheldrakee GN, et al. Environmentally benign perfluorooctanesulfonate alternatives using a $\mathrm{Zn} / \mathrm{CuI}$ mediated Michael-type addition in imidazolium ionic liquids. Green Chem 2014;16(5):2406-2410. 